\begin{tabular}{|l|l|l|l|l|l|}
\hline J. Tek. Ling & Vol. 12 & No. 3 & Hal. 283 - 290 & Jakarta, September 2011 & ISSN 1441-318X \\
\hline
\end{tabular}

\title{
PENURUNAN BAHAN ORGANIK AIR LIMBAH INDUSTRI PERMEN DENGAN MENGGUNAKAN REAKTOR PACKED BED BERDASARKAN VARIASI WAKTU TINGGAL
}

\author{
Titiresmi \\ Peneliti di Balai Teknologi Lingkungan \\ Badan Pengkajian dan Penerapan Teknologi
}

\begin{abstract}
Abstrak
Kandungan organik tinggi dari air limbah akan efisien dihilangkan digunakan bioreaktor gabungan, proses aerobik diikuti dengan proses aerobik. Dalam penelitian ini skala laboratorium percobaan bioreaktor packed bed didirikan. Air Limbah yang dipasang dalam penelitian ini diperoleh dari buangan dari air limbah proses aerobik PT Van Melle Indonedia. Karakteristik air limbah yang keruh, BOD / COD rasio 0,3-0,5 dan kandungan COD dalam kisaran $10.000-30.000 \mathrm{mg} / \mathrm{L}$. Dari sudut pandang biodegradabilitas, pengobatan mikrobiologi akan memberikan keuntungan lebih dari pada kimia atau pengolahan fisik. Langkah awal yang meliputi pengayakan dan aklimatisasi dijalankan untuk memperoleh populasi mikroba yang sesuai didalam bioreaktor packed bed. Langkah-langkah awal digunakan sistem batch sehingga mikroba yg berkembang akan melekat padauntuk mendukung bahan. Setelah itu mikroba yang tumbuh menyesuaikan diri dengan mengalirkan air limbah secara perlahan dan terus-menerus dan kolom. Percobaan menunjukkan bahwa efisiensi tertinggi, 96,55\%, diperoleh waktu retensi selama $24 \mathrm{jam}$. Efisiensi ini menurun bersama dengan waktu retensi dan peningkatan kandungan organik. Hasil uji bioreaktor packed bed penuh dengan bahan pendukung cincin plastik mampu menghilangkan kandungan organik lebih dari $80 \%$.
\end{abstract}

kata kunci: mikrobiologi, pembibitan, aklimatisasi, bioreaktor packed bed, air limbah

\begin{abstract}
High organic content of wastewater would be efficiently eliminated if combined bioreactor, anaerobic followed by aerobic processes, is utilized. In this study a laboratory scale trial of packed bed bioreactor was established. Wastewater used in this study was obtained from effluent of anaerobically processed wastewater of PT Van Melle Indonedia. Characteristics of the wastewater were turbid, BOD/COD ratio $0.3-0.5$ and COD contents in the range $10.000-30,000 \mathrm{mg} / \mathrm{L}$. From biodegradability point of view, microbiological treatment will provide more advantages than chemical or physical treatments. Preliminary steps that included seeding and acclimatization were run to obtain a suitable microbial population within the packed bed bioreactor. The preliminary steps utilized no flow batch column system as such the proliferated microbes will attach to support materials. Afterward the growing microbes were acclimated by flowing slowly and continually wastewater to the column. The trial showed that the highest efficiency, 96.55\%, was obtained for 24 hours retention time. The efficiency was decreasing along with reducing the retention time and increasing the organic content. Results of test of packed bed bioreactor filled with plastic ring support material were capable of eliminating organic content more than $80 \%$.
\end{abstract}

keywords: microbiology, seeding, acclimatization, packed bed bioreactor, wastewater

Penurunan Bahan Organik Air Limbah,... J.Tek. Ling. 12 (3): 283 - 290 


\section{PENDAHULUAN}

\subsection{Latar belakang}

Beragamnya jenis industri di Indonesia, menyebabkan beragam pula jenis limbah yang dihasilkan baik kualitas maupun kuantitasnya sehingga setiap jenis limbah baik padat, cair ataupun gas memerlukan pengelolaan sesuai dengan karakteristiknya guna mencegah terjadinya pencemaran lingkungan. Bagi kebanyakan industri, penanganan limbah adalah solusi mencari kompromi antara dampak negative yang terjadi pada lingkungan akibat kegiatan industri tersebut dengan minimisasi biaya agar tidak berpengaruh terhadap biaya produski. PT. Van Melle Indonesia merupakan salah satu industri permen yang menggunakan gula sebagai bahan baku utama sehingga berpotensi menghasilkan limbah dengan kandungan bahan organik tinggi dimana rasio $\mathrm{BOD} / \mathrm{COD}$ berkisar $0,3-0,5$ dan konsentrasi COD antara 10.000 - 30.000mg/l. Adapun sumber limbah tersebut dapat dilihat dari tahapan proses produksi pada Gambar 1 .

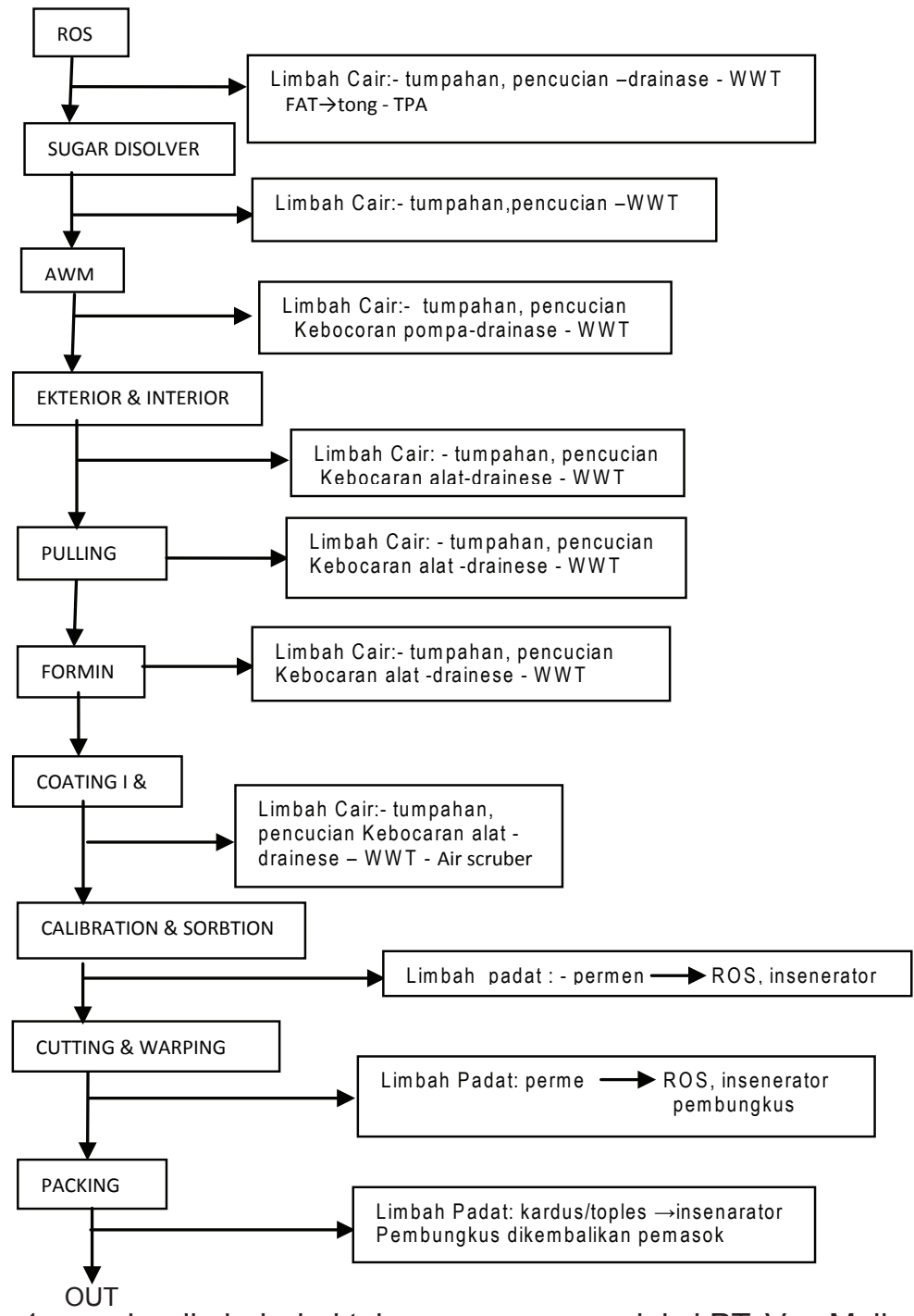

Gambar 1. sumber limbah dari tahapan proses produksi PT. Van Melle Indonesia. 
Penjelasan tahapan proses produksi adalah sebagai berikut :

1. ROS (Rework of Sugar), merupakan alat untuk mendaur ulang permen yang tidak lolos kualitasnya menjadi cairan kembali dengan cara pemanasan. ROS mempunyai beberapa bagian yaitu disolver, filtrasi strorage tank, preparation.

2. Sugar dissolver, pada unit ini cairan gula dari ROS akan diberi tambahan gula kristal dan dipanaskan kembali.

3. AWM (Automatic Weighing Machine), cairan gula akan diberi tambahan glukosa dan bahan-bahan lain sesuai dengan jenis kembang gula yang dibuat.

4. Pulling dan forming merupakan unit pengadukan dengan tujuan membuat kembang gula menjadi kenyal dan semua bahan-bahan tercampur rata dan diberi penambah rasa dan warna.

5. Coating $I$, alat pelapisan eksterior tahap I.

6. Drying room, didiamkan dalam ruang dengan suhu $30-40^{\circ} \mathrm{C}$ selama 24 jam.

7. Coating II, pelapisan eksterior tahap II sehingga lapisan menjadi sempurna.

8. Calibration \& sortilation, untuk memisahkan permen yang tidak lolos kualiti.

9. Pengepakan.

(Sumber : PT. Van Melle Indonesia, 1999).

Dilihat dari karakteristik limbah yang dihasilkan dengan kandungan bahan organik yang tinggi maka penggunaan bioreaktor gabungan anaerob - aerob adalah pilihan yang tepat karena lebih efesien. PT Van Melle Indonesia telah menggunakan sistem kombinasi tersebut, dimana proses anaerob yang digunakan adalah anaerob biobed reactor model EGSB (Extended Granular Sludge Blanked), sedangkan proses aerob menggunakan sistem activated sludge (extended aeration)
Alternatif pengolahan limbah dengan kandungan bahan organik yang tinggi dapat secara mikrobiologis, yaitu memanfaatkan mikroorganisme untuk menguraikan senyawa organik dalam air limbah menjadi senyawa yang sederhana1). Sistem pengolahan biologis ini mempunyai banyak kelebihan dibandingkan dengan sistem lain sehubungan dengan operasional, pemeliharaan dan efesiensi proses. Sedangkan kelemahannya adalah sering timbulnya bulking sludge yang mengganggu kinerja proses yang menyebabkan terganggunya pertumbuhan mikroorganisme.

Pada penelitian ini akan dilakukan uji coba pengolahan secara aerob dengan menggunakan reaktor packed bed skala laboratorium, yang dapat dipilih sebagai jenis reaktor lain untuk mengatasi masalah tersebut.

Kelebihan Reaktor packed-bed :

1. Dapat menguraikan bahan organik dan lebih tahan terhadap kejutan beban organik.

2. Dapat memanfaatkan sifat meningkatkan dan mempercepat pertumbuhan mikroorganisme pengurai yang akan mengkonsumsi bahan organik

3. Memberikan risiko cukup kecil dari efek terbuangnya biomassa (washout) dalam reaktor akibat gangguan proses sehingga biomassa akan tetap merekat pada media filter.

4. Proses pengolahan yang relatif stabil.

\subsection{REAKTOR PACKED - BED}

\section{a) Jenis Reaktor Berdasarkan Proses Mikrobiologis}

Reaktor packed-bed adalah salah satu jenis reaktor dengan menggunakan sistem aerobik biofilter dan merupakan bioreaktor lekat diam, dimana mikroorganisme akan 
tumbuh dan berkembang di atas suatu media inert yang terbuat dari plastik atau batu, serta membentuk suatu lapisan lendir untuk melekatkan diri di atas permukaan media tersebut yang akhirnya membentuk lapisan biofilm ${ }^{2}$. Proses yang terjadi di dalam reaktor packed-bed berlangsung dalam kondisi aerob dimana suplai oksigen diperlukan dalam proses ini.

Proses pengolahan air buangan secara mikrobiologis dapat berlangsung dalam tiga kondisi utama yaitu :

1. Lingkungan aerob, yaitu lingkungan dimana oksigen terlarut (DO) didalam air terdapat cukup banyak, sehingga oksigen bukan merupakan faktor pembatas.

2. Lingkungan anoksik, yaitu lingkungan dimana oksigen terlarut (DO) didalam air ada dalam konsentrasi rendah.

3. Lingkungan anaerob, merupakan kebalikan dari lingkungan areob, yaitu tidak terdapat oksigen terlarut, sehingga oksigen menjadi faktor pembatas berlangsungnya proses metabolisme aerob.

Berdasarkan atas kondisi lingkungan pertumbuhan mikroorganisme yang berperan pada proses penguraian yang terjadi, reaktor dapat dibedakan menjadi dua bagian ${ }^{2)}$ yaitu :

1. Reaktor pertumbuhan tersuspensi (Suspended Growth reactor) dimana mikroorganisme yang berperan pada proses biologis tumbuh dan berkembangbiak dalam keadaan tersuspensi.

2. Reaktor pertumbuhan lekat (attached growth reactor), dimana mikroorganisme yang berperan pada proses penguraian substrat tumbuh dan berkembang diatas suatu media (support) dengan membentuk suatu lapisan lendir untuk melekatkan diri diatas permukaan media tersebut dan membentuk lapisan biofilm. (Metcalf \& Eddy, 1991)

\section{b. Jenis reaktor berdasarkan aliran}

Menurut Chibata ${ }^{3)}$ reaktor packed-bed termasuk jenis reaktor aliran sumbat (plug flow). Gambar 2 menunjukkan jenis reaktor packed-bed yang banyak digunakan adalah a). down flow b). up Flow dan c). recycle (gambar 2). Dalam banyak kasus, reaktor down flow menyebabkan pemampatan dalam kolom sehingga up flow lebih umum digunakan.
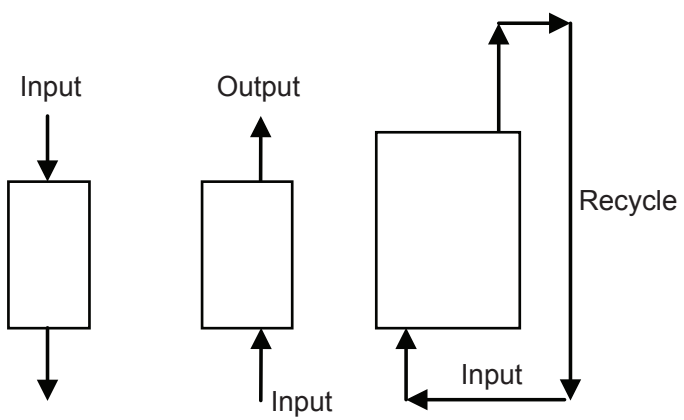
a) Down flow
b) up flow
c) recyccle

Gambar 2. Jenis reaktor packed bed

\section{c. Proses Metabolisme Biofilm}

Menurut Said (2001), mekanisme proses metabolisme didalam suatu biofilm secara aerob adalah seperti pada Gambar 3. Senyawa pencemar yang ada didalam air limbah misalnya senyawa organik (BOD,COD), ammonia, phosphor dan lainnya akan terdifusi kedalam lapisan biofilm yang melekat pada permukaan medium. Pada saat yang bersamaan dengan menggunakan oksigen yang terlarut didalam air limbah, senyawa pencemar tersebut akan diuraikan oleh mikroorganisme yang ada didalam lapisan biofilm, dan energi yang dihasilkan akan diubah menjadi biomasa4).

Jika lapisan mikrobiologis cukup tebal, maka pada bagian luar lapisan mikrobiologis akan berada dalam kondisi aerob, sedangkan pada bagian dalam biofilm yang melekat pada medium akan berada dalam kondisi anaerobik. Pada kondisi anaerobik akan 
terbentuk gas $\mathrm{H}_{2} \mathrm{~S}$, dan jika konsentrasi oksigen terlarut cukup besar maka gas $\mathrm{H}_{2} \mathrm{~S}$ yang terbentuk tersebut akan diubah menjadi sulfat $\left(\mathrm{SO}_{4}\right)$ oleh bakteri sulfat yang ada didalam biofilm ${ }^{1}$.

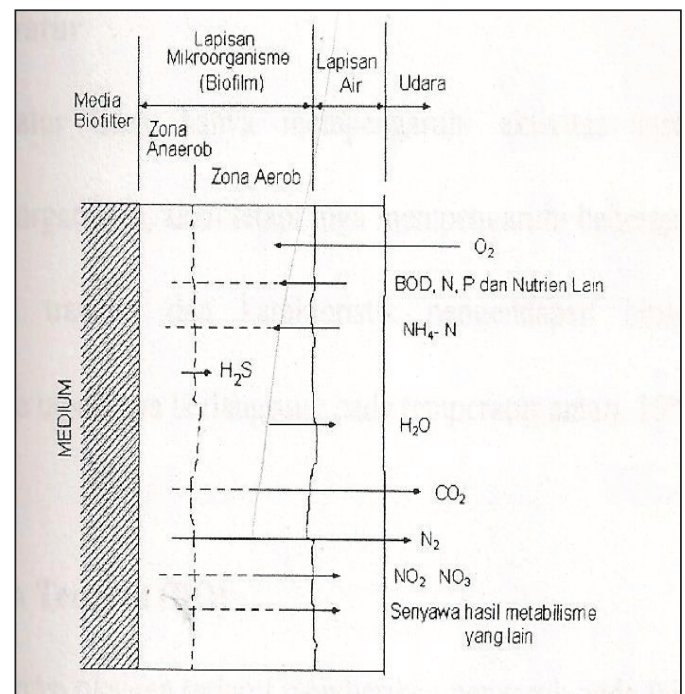

Gambar 3. Mekanisme Proses Metabolisme

Pada zona aerob, nitrogen-ammonium akan diubah menjadi nitrit dan nitrat dan selanjutnya pada zona anaerob nitrat yang terbentuk mengalami proses denitrifikasi menjadi gas nitrogen. Karena didalam sistem biofilm terjadi kondisi anaerob dan aerob pada saat yang bersamaan, maka proses penghilangan senyawa nitrogen akan menjadi mudah').

\section{d. Parameter penting dalam proses penguraian}

\section{1. $\mathrm{pH}$}

Randall (1980), menyatakan bahwa rentang $\mathrm{pH}$ yang paling luas (ekstrim) untuk proses pengolahan air buangan dan pertumbuhan bakteri adalah 4-9, dengan rentang pH optimum sekitar 6,5-7,5. Menurut Wilkinson yang dikutip oleh Randall (1980), pertumbuhan mikroorganisme terbaik pada $\mathrm{pH}$ yang mendekati basa, sedangkan algae dan fungi tumbuh baik pada $\mathrm{pH}$ yang mendekati asam ${ }^{6)}$

\section{Temperatur}

Temperatur tidak hanya mempengaruhi aktivitas metabolism dari populasi mikroorganisme, akan tetapi juga mempengaruhi beberapa faktor seperti kecepatan gas transfer dan karakterisrtik pengendapan biosolid. Aktifitas mikroorganisme umumnya berlangsung pada temparatur antara $15^{\circ} \mathrm{C}-30^{\circ} \mathrm{C}$.

\section{Oksigen Terlarut (DO)}

Konsentrasi oksigen terlarut memberikan pengaruh pada laju pertumbuhan bakteri aerobik dalam pengolahan secara mikrobiologis. Kehadiran oksigen terlarut dalam jumlah yang cukup sangat diperlukan untuk proses olsidasi dan sintesa sel. Oksigen dalam proses oksidasi ditujukan sebagai sumber elektron akseptor (Gaudy \& gaudy, $1981 ;{ }^{9}$ ).

\section{Nutrien}

Disamping kebutuhan akan karbon dan energi, mikroorganisme juga membutuhkan nutrien bagi sintesa sel dan untuk pertumbuhan. Kebutuhan akan nutrien tersebut dinyatakan dalam bentuk perbandingan antara karbon dan nitrogen serta phosphor yang merupakan nutrien anorganik utama yang diperlukan mikroorganisme dalam bentuk BOD:N:P= 100:5:1 (Randall,1980)

\section{Ketebalan Biofilm}

Ketebalan biofilm merupakan hal terpenting dalam proses aerob. Ketebalan ini harus berada antara ketebalan total biofilm dan ketebalan biofilm aktif. Tidak seluruh tebal lapisan biofilm berperan dalam penyisihan substrat. Ketebalan biofilm yang berperan dalam penyisihan substract disebut ketebalanbiofilm aktif atau efektif.

Menurut Winkler(1981), ketebalan biofilm 0,1 - 0,2 mm merupakan kondisi yang mana respirasi aerob terjadi dengan baik. Bila ketebalan lapisan biofilm lebih dari 0,2 $\mathrm{mm}$ akan berakibat oksigen yang terdifusi ke dalam lapisan biofilm tidak 
mencapai mikroorganisme yang berada dekat dengan media sehingga terbentuk suasana anaerob. Selain itu bila lapisan biofilm terlalu tebal akan berakibat materi organik yang diadsorbi selama air mengalir tidak mencapai mikroorganisme yang berada dekat media ${ }^{7}$.

\subsection{Tujuan penelitian}

1. Menguji kemampuan reaktor packed - bed dengan media cincin plastik untuk menyisihkan bahan organik dalam menggolah air buangan industri permen.

2. Mendapatkan waktu tinggal optimum terhadap penyisihan bahan pencemar organik.

\section{METODOLOGI}

\subsection{Bahan}

\section{a. Mikroorganisme}

Diambil dari bak aerasi instalasi pengolah limbah biologis PT.Van Melle Indonesia. Perbanyakan mikroorganisme (seeding) dilakukan dalam reaktor secara batch agar mikroorganisme yang tumbuh dapat langsung melekat pada media. Apabila pertumbuhan mikroorganisme sudah cukup dan stabil maka ,dilanjutkan dengan proses aklimatisasi atau adapatasi mikroorganisme terhadap air limbah yang mengalir secara kontinu. Untuk memelihara pertumbuhannya,maka selama seeding ditambahkan oksigen dengan menggunakan aerator dan diberi nutrien. Sedangkan untuk menjaga kestabilan media dan tingkat pertumbuhan mikroorganisme maka dilakukan pengukuran parameter $\mathrm{pH}$, Suhu, COD, VSS, dan TSS.

\section{b. Efluen}

Setelah melalui proses pengolahan secara anaerob, kualitas air limbah efluen mengalami peningkatan yang ditunjukkan oleh nilai COD dari 3000 mg/l menjadi 1070 mg/l. Tabel 1 dibawah ini menunjukkan kadar kualitas air limbah efluen setelah proses anaerob.

Tabel 1. Kadar kualitas air limbah efluen proses anaerob PT. Van Melle Indonesia

\begin{tabular}{|c|c|c|}
\hline PARAMETER & SATUAN & HASIL ANALISA \\
\hline TSS & $\mathrm{mg} / \mathrm{l}$ & 400 \\
\hline TDS & $\mathrm{mg} / \mathrm{l}$ & 3200 \\
\hline $\mathrm{pH}$ & $\mathrm{mg} / \mathrm{l}$ & 7.5 \\
\hline $\mathrm{COD}$ & $\mathrm{mg} / \mathrm{l}$ & 1070 \\
\hline BOD & $\mathrm{mg} / \mathrm{l}$ & 570 \\
\hline Total $\mathrm{N}$ & $\mathrm{mg} / \mathrm{l}$ & 12 \\
\hline Total P & $\mathrm{mg} / \mathrm{l}$ & 0.5 \\
\hline
\end{tabular}

Sumber: Laboratorium Nusantara Water Center (2001)

\subsection{Persiapan Reaktor}

Model instalasi reaktor skala laboratorium yang digunakan dalam percobaan ini dapat dilihat pada gambar 4 dibawah ini :

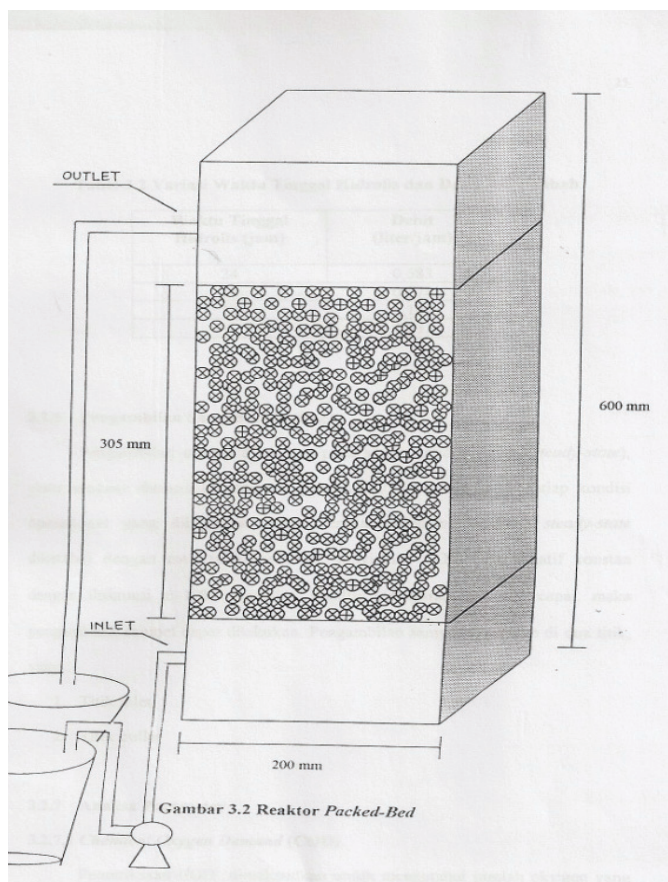

Gambar 4, reaktor Packed Bed 
Sedangkan spesifikasi reaktor disajikan pada Table 2 dibawah ini :

Tabel 2. Spesifikasi Reaktor Feed back

\begin{tabular}{|l|l|}
\hline URAIAN & KETERANGAN \\
\hline Model reactor terbuat dari: & Bahan aklirik \\
- Tinggi & $600 \mathrm{~mm}$ \\
- Luas alas & $200 \times 200 \mathrm{~mm}$ \\
\hline Media pendukung: & Cincin Plastik \\
Tinggi tumpukan media & $305 \mathrm{~mm}$ \\
Luas spesifik & $662 \mathrm{~m} 2 / \mathrm{m3}$ \\
Warna & putih \\
\hline Tangki reservoir: & \\
- Kapasitas & $15 \mathrm{~L}$ \\
- Bahan & Plastik \\
\hline Pompa: & \\
- Jenis & Peristaltik \\
\hline
\end{tabular}

\subsection{Pengoperasian Reaktor}

Penelitian ini dilakukan dengan mengoperasikan reactor secara kontinu untuk beberapa variasi waktu tinggal (WTH) yaitu 24 jam, 18 jam, 12 jam, dan 6 jam. Tabel 3 dibawah ini menunjukkan variasi waktu tinggal dan debit

Tabel 3. Variasi waktu tinggal dan debit Waktu Tinggal

\begin{tabular}{|c|c|}
\hline Hidrolis (liter/jam) & Debit (Jam) \\
\hline 24 & 0.583 \\
\hline 18 & 0.778 \\
\hline 12 & 1.167 \\
\hline 6 & 2.333 \\
\hline
\end{tabular}

\subsection{Pengambilan sampel}

Dilakukan di dua titik yaitu inlet dan outlet. Sampel diambil pada keadaan dimana kemampuan pengolahan di reaktor untuk setiap kondisi operasional sudah berjalan konstan yang dapat diketahui dengan mengamati dengan besarnya penyisihan COD yang realtif konstan dengan fluktuasi $+10 \%$.

\section{HASIL PERCOBAAN DAN PEMBAHASAN}

Pada tahap pengoperasian, reaktor dioperasikan secara kontinu dan dilakukan pengamatan pada setiap Waktu Tinggal Hidrolis (WTH) yang bervariasi, yaitu 24 jam, 18 jam,12 jam, dan 6 jam. Tujuannya adalah untuk menguji kemampuan reaktor pakcedbed dalam menyisihkan bahan organik yang dinyatakan dalam COD yang terkandung dalam limbah permen. Pengambilan data pada penelitian inti adalah pada saat kondisi sistem di dalam reaktor sudah stabil. Kinerja reaktor packed-bed dalam menyisihkan bahan organik dapat dilihat pada Tabel 4 .

Tabel 4. Penyisihan Bahan Organik Pada Reaktor Packed-bed

\begin{tabular}{|c|c|r|c|}
\hline $\begin{array}{c}\text { WTH } \\
\text { (jam) }\end{array}$ & $\begin{array}{c}\text { COD } \\
(\mathrm{mg} / \mathrm{l})\end{array}$ & $\begin{array}{c}\text { Efisiensi } \\
(\%)\end{array}$ & \\
\hline & Influen & Efluen & \\
\hline \multirow{2}{*}{24} & 1301.53 & 47.56 & 35.95 \\
& 1110.48 & 96.35 & 96.76 \\
\hline Rata-rata & 1206.005 & 41.755 & 96.55 \\
\hline \multirow{2}{*}{18} & 1198.66 & 58 & 95.16 \\
& 1232.95 & 60.45 & 95.10 \\
\hline Rata-rata & 1215.80 & 59.23 & 95.13 \\
\hline \multirow{2}{*}{12} & 870.43 & 45.75 & 94.13 \\
& 757.75 & 45.75 & 93.96 \\
\hline Rata-rata & 814.09 & 45.75 & 94.35 \\
\hline \multirow{2}{*}{6} & 1078.53 & 131.22 & 87.83 \\
& 1074.06 & 129.73 & 87.92 \\
\hline Rata-rata & 1076.295 & 130.475 & 87.88 \\
\hline
\end{tabular}

Pada Tabel 4 terlihat bahwa efisiensi penyisihan bahan organik semakin lama semakin menurun sejalan dengan berkurangnya waktu tinggal hidrolis. Dari hasil penelitian ini menunjukkan bahwa semakin pendek waktu tinggal hidrolis, yaitu dari 24 jam sampai dengan 6 jam, maka efisiensi penyisihan rata-rata bahan organik juga semakin berkurang, dari $96.55 \%$ sampai dengan $87,88 \%$. Hal ini disebabkan karena semakin lama waktu tinggal hidrolis air limbah di dalam reaktor, maka semakin lama waktu kontak antara mikroorganisme (biofilm) dengan air limbah sehingga bakteri heterotrof dan autotrof semakin leluasa untuk mengoksidasinya. 
Waktu kontak antara mikroorganisme dengan air limbah yang mengandung bahan organik sangat berpengaruh pada proses penyerapan bahan organik dan oksidasi zat. Sedangkan grafik penyisihan bahan organik terhadap waktu tinggal hidrolis dapat dilihat pada gambar 4. Hubungan antara efisiensi penyisihan rata-rata bahan organik dengan waktu tinggal hidrolis dapat dilihat dengan melakukan analisa regresi, dimana koefinsiensi determinasi yang diperoleh sebesar 0.8107 .

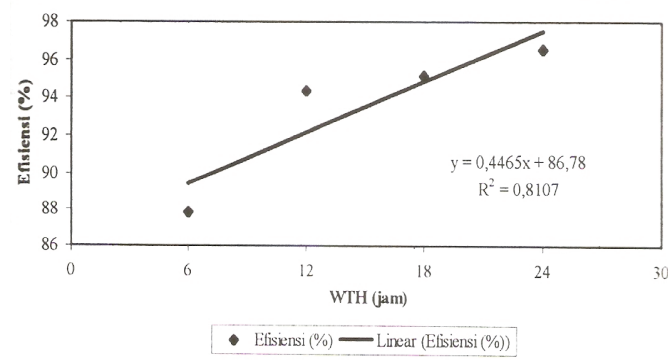

Gambar 4.5 Grafik Penyisihan Bahan Organik Terhadap Waktu Tinggal Hidrolis

\section{KESIMPULAN}

Dari hasil penelitian dengan menggunakan reaktor packed-bed dan media cincin plastik terhadap proses penyisihan bahan organik dapat disimpulkan:

1. Tingkat efisiensi penyisihan tertinggi dicapai pada waktu tinggal 24 jam, yaitu sebesar $96,55 \%$.

2. Waktu tinggal hidrolis (WTH) berpengaruh positif terhadap besarnya efisiensi penyisihan bahan organik, ditunjukkan pada nilai koefisiensi determinasi sebesar 0.8107 .

3. Tingkat efisiensi penyisihan bahan organik menurun sejalan dengan penurunan waktu tinggal.

\section{UCAPAN TERIMA KASIH}

Penulis mengucapkan terima kasih kepada sdri.Pandan Nilasari serta kawan kawan di Laboratorium Analitik dan laboratorium Proses, Balai Teknologi Lingkungan yang telah melakukan pengamatan dan analisa parameter uji. Juga kepada sdr Anto, sdr Diono, mbak Dwi dan mbak Ikha yang telah banyak membantu dalam menyelesaikan tulisan ini

\section{DAFTAR PUSTAKA}

1. Djajadiningrat, A.H dan Wisjnuprapto.1990. Biorekator Pengolahan Limbah cair. Bandung: Institut Teknologi Bandung.

2. Metcalf and Eddy 19991. Wastewater Enginering, Traetment, Dispposal, Rouse, New York : MC Grow Hill

3. Chibata, I. 1978. Immobilized Enzymes,Kogansha, Tokyo

4. Said. Nusa Idaman, 2000. Pengolahan Air Limbah Dengan Proses Biofilter Anaerob-Aerob. Jurnal Teknologi Lingkungan Vol 1 No.1/2: Jakarta.

5. Arvin, E and Herremoes. 1990. Concept and Models For Biofilm Reactor Permormance. Water Science

Technology, vol.22 no. 1/ 2 pp 171-192: London

6. Benefield, Larry D and Randall, Clifford. W. 1980. Biological Processes Design For Wastewater Treatmen.

7. Winkler,M.A. 1981. Biological treatment Of Wastewater. West Sussex: John Willey and Sons

8. AWWA. 1989. Standart Method For The Examination Of Water And Wastewater, $15^{\text {th }}$ ed. Washington.

9. Gaudy, C.P.L. \& Lim, H.C. 1980. Biologycal Waste water Treatment. New York: Marcel Dekker, Inc 